$\mathbf{F c} \gamma$ 受容体発現レポーター細胞を用いた抗体医薬品の品質評価

\author{
多田稔, * 石井明子
}

\title{
Characterization of Therapeutic Monoclonal Antibodies by Using Fc $\gamma$ R-expressing Reporter Cell Lines
}

\author{
Minoru Tada* and Akiko Ishii-Watabe \\ Division of Biological Chemistry and Biologicals, National Institute of Health Sciences; \\ 1-18-1 Kamiyoga, Setagaya-ku, Tokyo 158-8501, Japan.
}

(Received October 22, 2016)

\begin{abstract}
$\mathrm{Fc} \gamma$ receptors (Fc $\gamma \mathrm{Rs}$ ), which bind to the Fc regions of antibodies, play an important role in antibody effector functions. In humans, there are four types of activating Fc $\gamma$ Rs: Fc $\gamma$ RI, Fc $\gamma$ RIIa, Fc $\gamma$ RIIIa, and Fc $\gamma$ RIIIb. These are expressed on various effector cells such as natural killer (NK) cells, neutrophils and macrophages. Fc $\gamma$ RIIIa expressed on NK cells is known to play a pivotal role in antibody-dependent cellular cytotoxicity (ADCC) by therapeutic monoclonal antibodies (mAbs). To assess the ADCC activity of mAbs, the killing of target cells is often measured using human peripheral mononuclear blood cells (hPBMCs) or isolated primary NK cells as effector cells. These assays can directly assess the cytotoxicity induced by mAbs, but require fresh blood from donors, and are insufficiently reproducible due to differences in effector cell activity among donors. We developed a cell-based assay using reporter cell lines expressing human Fc $\gamma \mathrm{R}$ and a nuclear factor of activated T cells (NFAT) -driven luciferase reporter gene (Jurkat/Fc $\gamma$ R/NFAT-Luc), which can estimate the activation of various $\mathrm{Fc} \gamma \mathrm{Rs}$ by antigen-bound mAbs in vitro, with high reproducibility. The usefulness of this assay was confirmed by comparing mAbs activity with different abilities to activate Fc $\gamma$ Rs, including Fc-engineered anti-CD20 mAbs and anti-EGFR mAbs with different IgG subclasses. We also confirmed the application of this assay for the characterization of mAbs product-related substances. Our Fc $\gamma \mathrm{R}$ reporter assay is a promising new tool for the characterization of therapeutic mAbs in various stages of mAbs development.
\end{abstract}

Key words_-monoclonal antibody; Fc $\gamma$ receptor; characterization

\section{1. はじめに}

抗体医薬品は種々の悪性腫瘍や免疫疾患などの治 療に貢献しており，最も成功をおさめたバイオ医薬 品の 1 つであると言える。抗体（immunoglobulin G; IgG）は各 2 本の重鎖及び軽鎖から構成される 分子量約 15 万の糖タンパク質であり，その分子構 造は，抗原結合に関与する fragment antibody binding (Fab) 領域と, 免疫エフェクター機能等の発 揮に関与する fragment crystallizable $(\mathrm{Fc})$ 領域に 大別される. 抗体医薬品の薬理作用の発揮において は， $\mathrm{Fab}$ 領域を介した標的抗原への特異的な結合が 主要な役割を果たすことは言うまでもないが，Fc

国立医薬品食品衛生研究所生物薬品部（干158-8501 東 京都世田谷区上用賀 1-18-1)

*e-mail: m-tada@nihs.go.jp

本総説は, 日本薬学会第 136 年会シンポジウム S18 で 発表した内容を中心に記述したものである.
領域を介した補体経路や Fcy 受容体の活性化に伴 う，補体依存性細胞傷害 (complement-dependent cytotoxicity; CDC) 活性や抗体依存性細胞傷害 (antibody-dependent cellular cytotoxicity; ADCC) 活性の発揮は, 標的抗原発現細胞の除去を目的とす る抗腫瘍抗体医薬品における重要な薬理作用メカニ ズムの 1 つである. 一方で，Fc 領域を介したこれ ら免疫経路の活性化は, 意図せぬサイトカイン放出 等の有害作用発現につながる可能性も考えられる.

$\mathrm{Fc}$ 領域は多くの抗体医薬品に共通の機能ドメイン である一方で, 有効性や安全性への寄与は抗体に よって異なること，また Fc 領域の機能は糖鎖修飾 等の様々な翻訳後修飾の影響を受け易いことから, 抗体医薬品の薬理作用や品質の評価において Fc 領 域の機能評価は重要であると言える。本稿ではわれ われが開発した F $\gamma$ 受容体発現レポーター細胞株 を用いた cell-based assay について概説するととも 


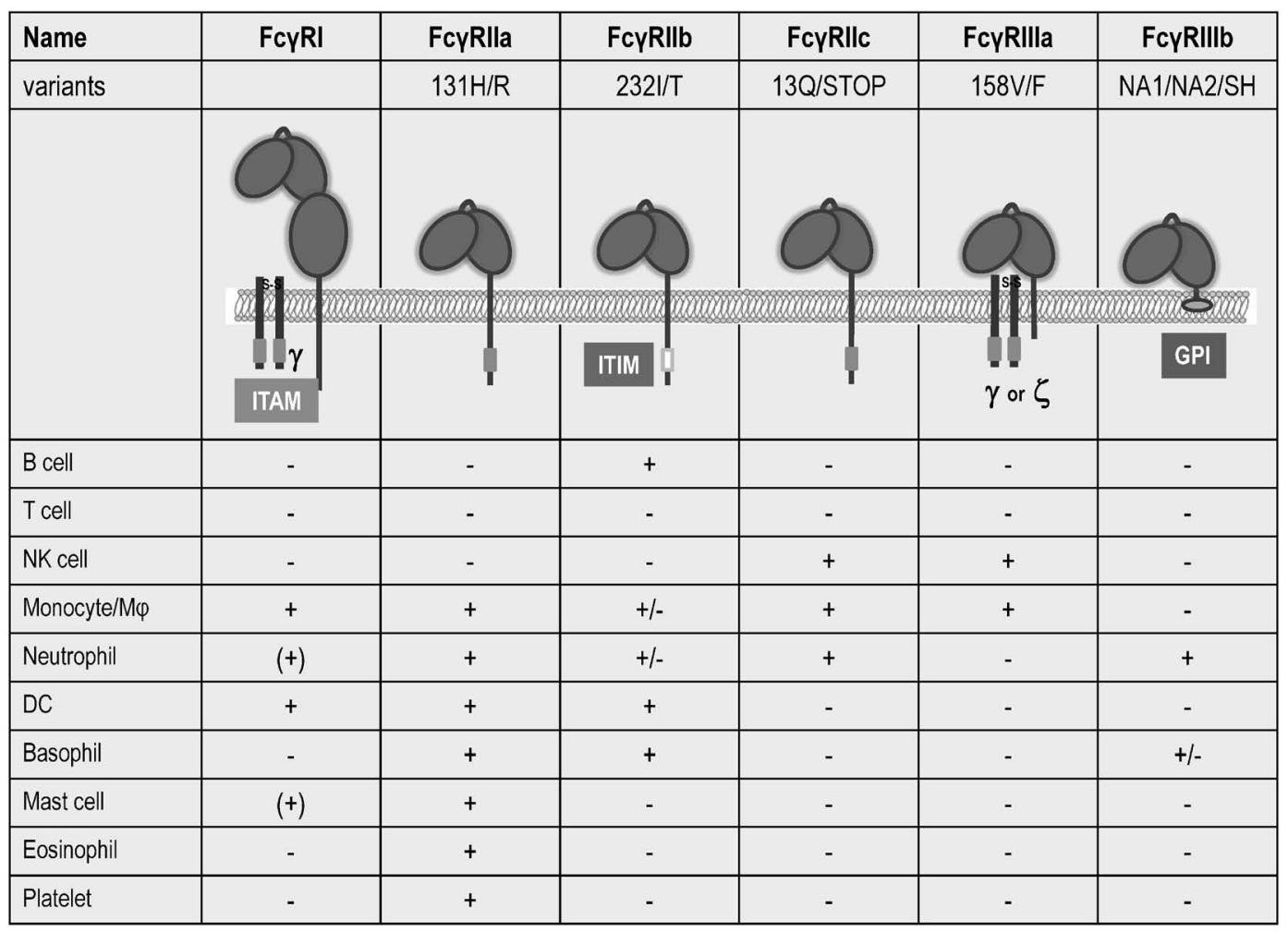

Fig. 1. Human Fc $\gamma$ R Family

Expression profiles of human Fc $\gamma \mathrm{R}$ family are described on the basis of literature data. ${ }^{1)}+$, expression; $(+)$, inducible expression; $+/-$, expression in low percentages subsets; - , no expression.

に, これを用いた抗体医薬品の特性解析の例につい て紹介する.

2. 抗体医薬品の有効性, 安全性に関与する Fc $\gamma$ 受容体ファミリー

ヒトにおいては機能と発現分布の異なる 6 種類の F $~ \gamma$ 受容体が存在しており, 一部の受容体について は受容体機能と密接に関与する遺伝子多型が存在し ている (Fig. 1).1,2)このうち, Fc $\gamma$ RI は他の Fc $\gamma$ 受 容体とは異なり, IgG と強い相互作用を示す高親和 性受容体である特徵を有している。 また，Fc $\gamma$ RIIb は F c y 受容体ファミリーの中で唯一, 抑制性の細 胞内シグナル伝達を担う F c y 受容体である。抗体 医薬品の ADCC 活性の発揮においては, ナチュラ ルキラー（natural killer; NK）細胞に発現する Fc $\gamma$ RIIIa が主要な役割を果たしており，抗体との 結合親和性の異なる Fc $\gamma$ RIIIa の遺伝子多型 $(158 \mathrm{~F}$ / V) が ADCC 活性に密接に関与することが知られ ている，ADCC 活性を増強する目的で，抗体の糖 鎖構造を改変することで Fc $\gamma$ RIIIa 結合親和性を高 めた抗体医薬品が開発され, 国内外で実用化にい たっている. ${ }^{3-5)}$ また NK 細胞以外に, 単球, マク
ロファージ，好中球等の免疫細胞にも種々の Fc $\gamma$ 受容体が発現しており，抗原に結合した抗体が Fc $\gamma$ 受容体を介してこれら免疫細胞を活性化することに より，標的細胞に対する細胞傷害活性や標的細胞の 食食作用が発揮される。加えて，近年では，樹状細 胞が F c $\gamma$ 受容体を介して腫瘍抗原一抗体医薬品複合 体を領食して腫瘍関連抗原の抗原提示を担うこと で，抗腫瘍免疫を活性化することも報告されてい る. ${ }^{6,7)}$ 一方で, 抗体医薬品あるいは抗原及び抗体医 薬品により形成される免疫複合体による F c $\gamma$ 受容 体の活性化は，意図せぬサイトカイン放出等に起因 する有害作用の発現や，抗体医薬品に対する抗薬物 抗体の産生にも関与すると考えられる。このように $\mathrm{F} c \gamma$ 受容体を介した免疫細胞の活性化は, 抗体医薬 品の有効性及び安全性に密接に関与していることか ら，標的とする抗原及び抗体医薬品の特性（IgG サ ブクラス, 改変等) を踏まえた Fc $\gamma$ 受容体結合・ 活性化能の評価が重要であると言える.

\section{3. 抗体医薬品の $\mathbf{F} \boldsymbol{\gamma} \gamma$ 受容体を介した機能評価}

抗体医薬品の $\mathrm{Fc} \gamma$ 受容体を介した機能評価法の 1 つとして, ヒト Fc $\gamma$ 受容体のリコンビナントタン 


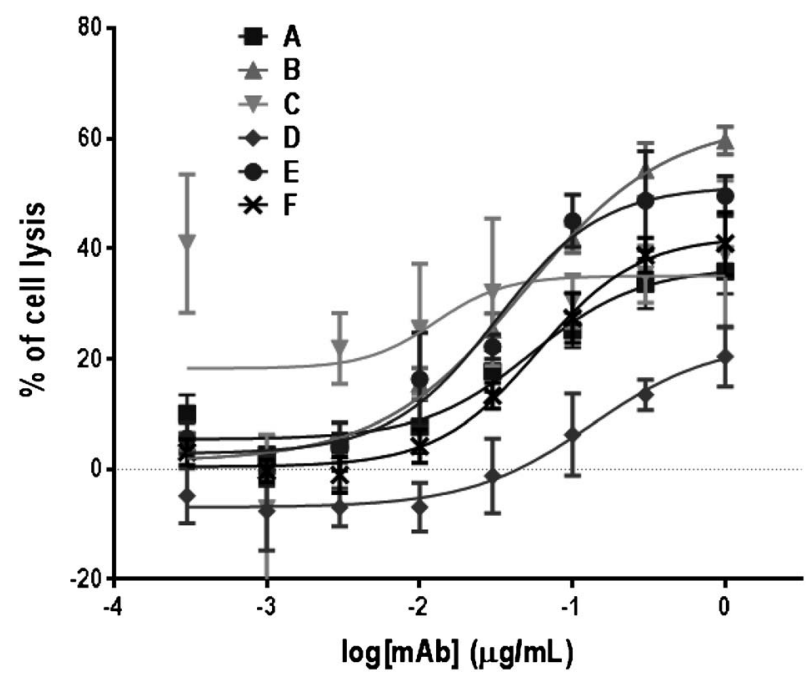

Fig. 2. Traditional ADCC Assay Using hPBMCs from Different Donors

Daudi cells and hPBMCs (donor A to F) were co-cultured in the presence of serially diluted rituximab. Percentages of cell lysis were calculated from lactate dehydrogenase activities released into the culture supernatant.

パク質を用いた in vitro 結合実験が挙げられる. 特 に表面プラズモン共鳴（surface plasmon resonance; SPR）法は，抗体 Fc 領域と Fc $\gamma$ 受容体との相互作 用について結合速度定数及び解離速度定数に基づく 解析が可能であり, 抗体 $\mathrm{Fc}$ 領域のアミノ酸置換や 糖鎖改変による $\mathrm{Fc} \gamma$ 受容体結合親和性の変化, 抗 体医薬品の分子変化体の $\mathrm{F} c \gamma$ 受容体結合能の評価 など，改変型抗体のデザインから品質管理手法の構 築にいたるまで抗体医薬品開発の様々な段階におい て汎用される優れた手法であると言える。一方で,

Fc $\gamma$ RI を除くすべてのヒト F $\gamma$ 受容体は単量体の抗 体に対する結合親和性が低く，主に抗原に結合した 抗体（免疫複合体）の受容体として機能すること,

また，これら Fc $\gamma$ 受容体の活性化は，抗原の性質 や抗体による認識部位（エピトープ）に起因する免 疫複合体の形成様式の違い等による影響をうけるこ とから，抗体医薬品の $\mathrm{F} c \gamma$ 受容体を介した機能評 価においては，標的抗原の存在する in vivoにより 近い環境下での $\mathrm{F} c \gamma$ 受容体活性化能の評価も重要 であると言える. F $\gamma$ 受容体活性化能を評価する上 ではヒト Fc $\gamma$ 受容体を発現するエフェクター細胞 が必須であるが，有用な株化細胞株が限られている ことなどから，ADCC 活性等の測定の際には，工 フェクター細胞としてヒト由来の全血や，そこから 単離したヒト末梢血単核球 (human peripheral blood mononuclear cell; hPBMC) 等が用いられる ことが多いのが現状である。これら初代培養細胞等
を用いた評価系には，ヒト生体内により近い環境で 抗体医薬品の作用を評価可能であるという利点があ る一方で, 提供者の確保を含む安定供給の困難さ, 試料調製の煩雑さ，提供者の個人差（Fcy 受容体の 遺伝子多型等）や試料調製に起因する試験の再現性 の低さなどの様々な課題が存在している. 実際にわ れわれが市販の複数ドナー由来の hPBMCを工 フェクター細胞として用いて抗 CD20 抗体リツキシ マブの ADCC 活性を測定した結果を Fig. 2 に示 す. 同一の抗体医薬品及び標的細胞の組み合わせ であっても, hPBMCのドナーの違いによって ADCC 活性が顕著に異なることが明らかである. hPBMC 等の初代培養細胞を用いる際には, このよ うな問題点を踏まえた上でアッセイ系を構築する必 要があり, 特に碩健性を要する医薬品の規格及び試 験方法等への適用は困難であると言える.

4. F $y$ 受容体発現レポーター細胞株を用いた $\mathbf{F c} \gamma$ 受容体活性化能評価系の構築

$\mathrm{hPBMC}$ 等の初代培養細胞を用いた従来の評価系 の持つ上記の課題を解決すべく, われわれはより簡 便に再現性よく Fc $\gamma$ 受容体の活性化を評価可能な アッセイ系の構築に取り組んできた. 抗体による標 的細胞に対する ADCC 活性は，(1)抗体による標的 細胞表面抗原の認識, (2)抗体の $\mathrm{Fc}$ 領域を介した工 フェクター細胞上の Fc $\gamma$ 受容体との結合, (3) F c $\gamma$ 受 容体の架橋刺激に伴うエフェクター細胞の活性化, (4)細胞傷害性物質の放出による標的細胞死の誘導の 
A
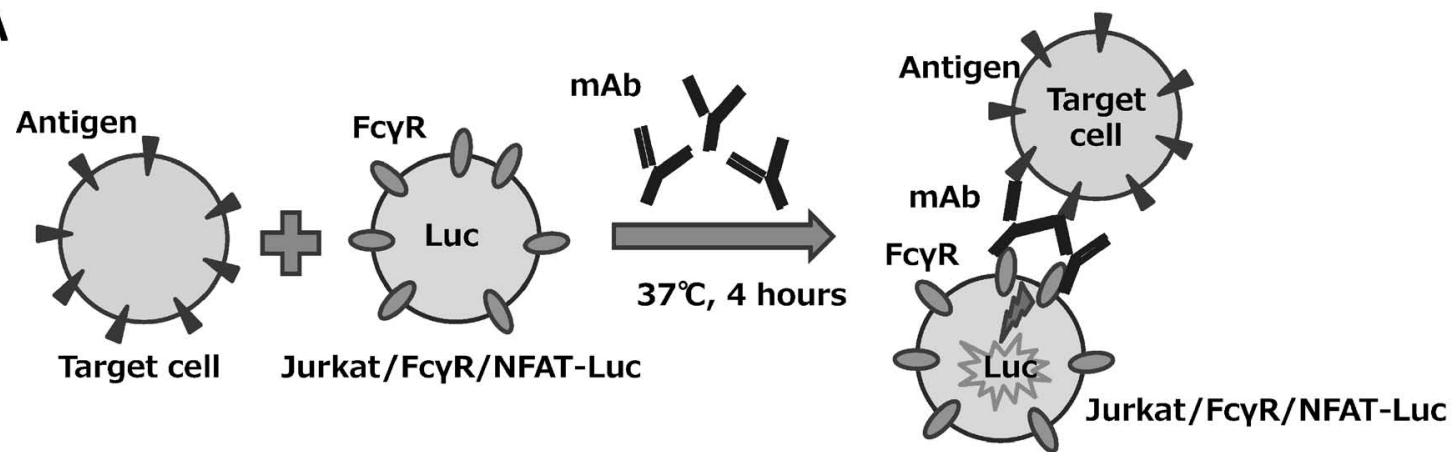

B

Traditional ADCC Assay

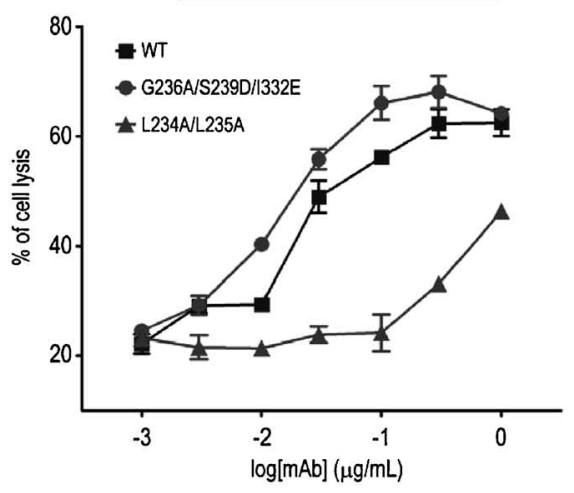

Our Reporter Assay (FcyRIIIa)

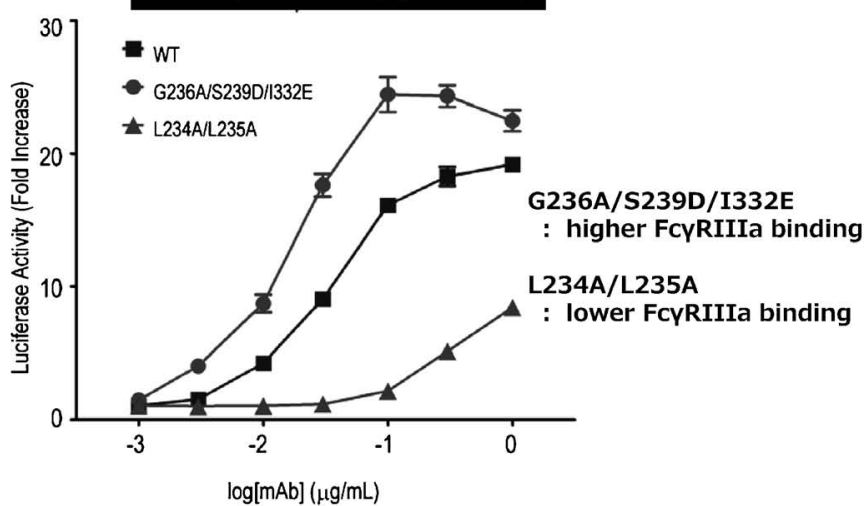

Fig. 3. Fc $\gamma$ R Activation Assay Using Jurkat/Fc $\gamma$ R/NFAT-Luc Cells

(A) Schematic model of Fc $\gamma \mathrm{R}$ activation assay using Jurkat/Fc $\gamma \mathrm{R} / \mathrm{NFAT}$-Luc cells. (B) Comparison between traditional ADCC assay using hPBMC and our reporter assay.

段階を経て発揮される。このうちわれわれは，(3)の エフェクター細胞の活性化, 特に細胞内シグナル伝 達の亢進に伴う細胞内カルシウム濃度の上昇に着目 し, 内在性の Fc $\gamma$ 受容体の発現を欠くJurkat 細胞 に，カルシウムシグナル応答性の転写因子である nuclear factor of activated T cells (NFAT) の制御 下でルシフェラーゼを発現するレポーター遺伝子 (NFAT-Luc) 及びヒト Fc $\gamma$ 受容体を発現するレポー 夕一細胞株（Jurkat/Fc $\gamma$ R/NFAT-Luc）を樹立し た. ${ }^{8)}$ 本細胞株では, $F \mathrm{c} \gamma$ 受容体の架橋刺激に伴う 細胞内カルシウム濃度の上昇の結果, NFAT によ るルシフェラーゼ遺伝子の転写が生じることから,

$\mathrm{F} c \gamma$ 受容体の活性化をルシフェラーゼ活性として検 出することが可能である。まず，樹立した Fc $\gamma$ RIIIa 発現レポーター細胞株 (Jurkat/Fc $\gamma$ RIIIa/ NFAT-Luc）に関して，抗体医薬品の ADCC 活性 測定系の代替法としての適用可能性について検討を 行った。抗原発現細胞及び Jurkat / Fc $\gamma$ RIIIa / NFAT-Luc を 96 穴プレートに播種し, 抗体医薬品 存在下で 4 時間培養した後, ルシフェラーゼ活性を
測定した結果，抗体添加濃度に依存したルシフェ ラーゼ活性の上昇が検出された。 また, Fc $\gamma$ 受容体 親和性の異なる改変型抗 CD20 抗体を用いた検討の 結果, 本評価系は hPBMC を用いた従来法と同様 に Fc $\gamma$ 受容体親和性の異なる抗体の ADCC 活性の 差異を評価可能であることが示された（Fig. 3). ${ }^{8)}$

次に, Fc $\gamma$ RIIa 発現レポーター細胞株 (Jurkat/ Fc $\gamma$ RIIa/NFAT-Luc) を用いて, IgG サブクラスの 異なる抗 EGFR 抗体による Fc $\gamma$ 受容体活性化につ いて検討を行った。 ヒト IgG1 骨格を有するセツキ シマブは Fc $\gamma$ RIIIa を発現する NK 細胞による ADCC 活性を発揮する一方で, Fc $\gamma$ RIIIa 結合親和 性の弱いヒト IgG2 骨格を有するパニツムマブは $\mathrm{NK}$ 細胞による ADCC 活性を発揮しないことが知 られている。 その一方で，パニッムマブは NK 細胞 以外の多核球や単球を介して EGFR 発現細胞に対 する細胞傷害活性を示すことが報告されており, ${ }^{9}$ Fc $\gamma$ RIIIa 以外の Fc $\gamma$ 受容体を活性化することによ り細胞傷害活性を発揮することが示唆されている.

EGFR を高発現するA431 細胞を標的として，セツ 

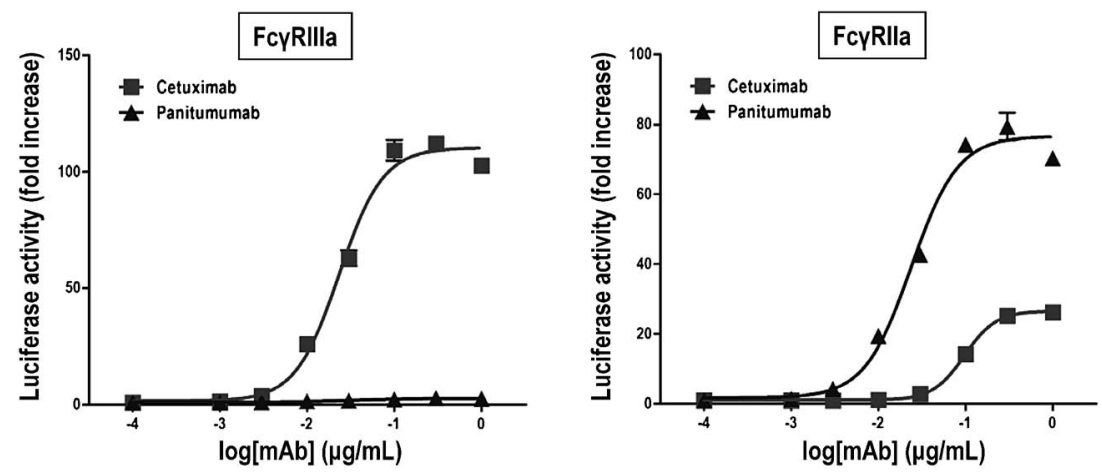

Fig. 4. Comparison of EGFR Binding-dependent Fc $\gamma$ Rs Activation between Cetuximab (human-mouse chimeric IgG1) and Panitumumab (human $\operatorname{IgG} 2$ )

\section{A}
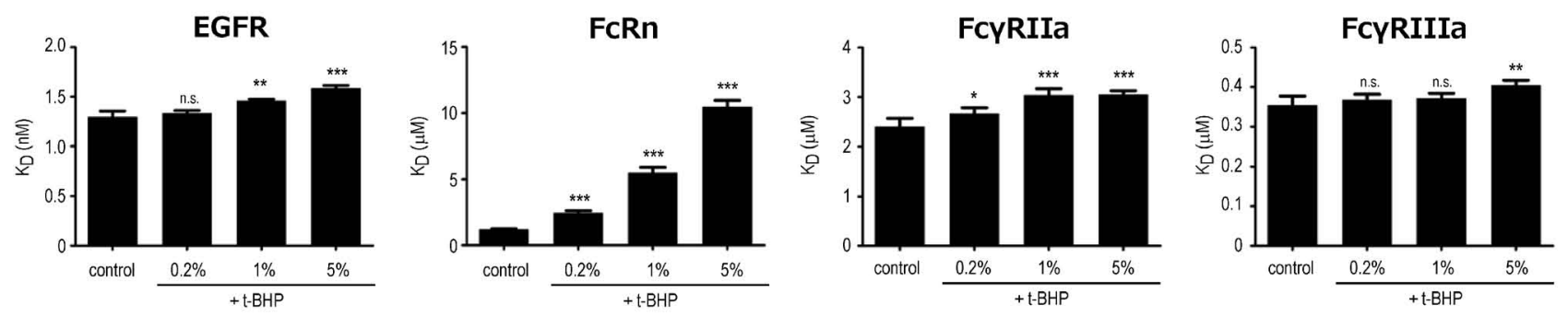

B
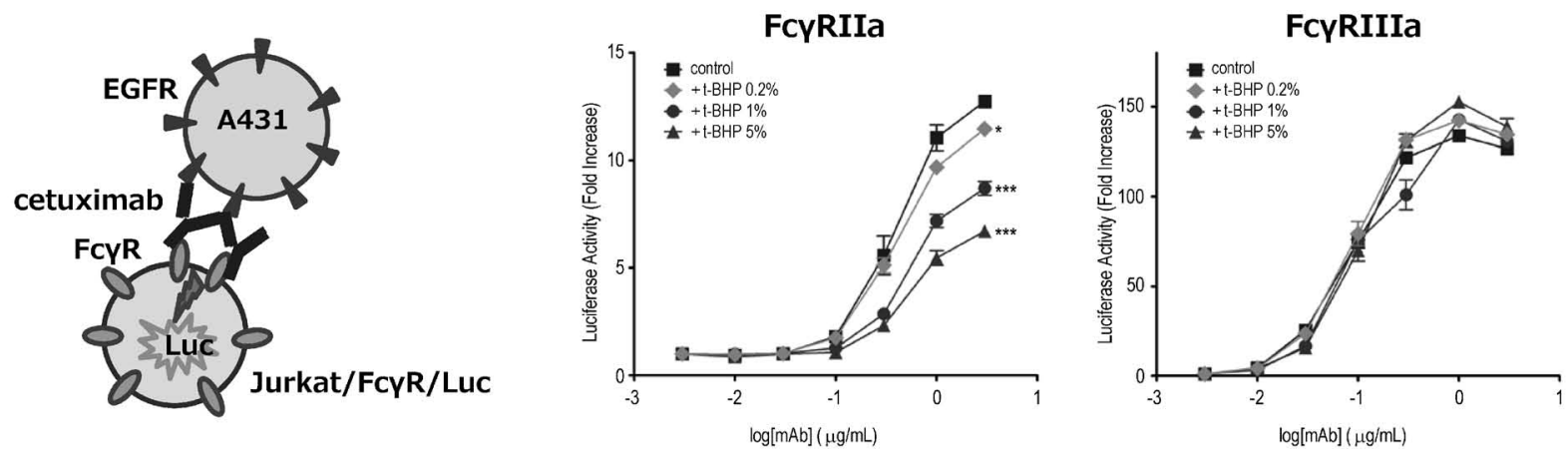

Fig. 5. Effects of $t$-BHP Mediated Forced Oxidation on the Biological Activities of Cetuximab (A) Non cell-based binding assay (SPR method). (B) Cell-based assay ( Fc $\gamma \mathrm{R}$ reporter assay).

キシマブ及びパニツムマブの抗原結合に依存した Fc $\gamma$ 受容体活性化能を測定した結果，Fc $\gamma$ RIIIa を 顕著に活性化するセツキシマブとは異なり，パニツ ムマブは Fc $\gamma$ RIIIa を活性化しない一方で Fc $\gamma$ RIIa を強く活性化することが明らかとなった（Fig. 4). ${ }^{8)}$ この結果は, パニツムマブが Fc $\gamma$ RIIIa 以外の F c $\gamma$ 受容体を介して細胞傷害活性を発揮するという 過去の報告を支持するものであり，われわれの構築
した Jurkat/Fc $\gamma$ RIIa/NFAT-Luc が顆粒球や単球と いった NK 細胞以外のエフェクター細胞を介した細 胞傷害活性の予測・評価に有用であることを示唆す るものである.

\section{5. 抗体医薬品の特性解析への応用}

高分子量タンパク質である抗体医薬品は，糖鎖修 飾等の翻訳後修飾の影響により様々な分子変化体を 含む不均一な分子集団である．抗体医薬品の品質管 
理の上では，主要な分子変化体についてはその特性 を明らかにした上で，品質管理戦略を構築すること が重要であり，特に抗体医薬品の有効性への寄与の 大きい生物活性への影響を解析することは必須であ ると言える.ここでは，われわれの構築した評価系 の抗体医薬品の特性解析への応用例として, 抗体医 薬品の強制酸化試料の $\mathrm{F} c \gamma$ 受容体活性化能の変化 を測定した例を紹介する. メチオニン残基等の酸化 は多くのタンパク質において生じる代表的な翻訳後 修飾であり，特に抗体医薬品の製造工程において生 じる Fc 領域のメチオニン残基の酸化は，抗体医薬 品の血中半減期制御に関与する FcRn との結合能を 著しく低下させることが知られている. ${ }^{10)}$ また，一 部の抗体医薬品では，抗原結合部位における酸化修 飾が抗原結合能を低下させることも報告されている 一方で, ${ }^{11)}$ 抗体医薬品の酸化が F $\gamma$ 受容体への結合 及び活性化に及ぼす影響については未解明な点が多 い.そこでわれわれは抗 EGFR 抗体セツキシマブ を試料として, tert-butyl hydroperoxide ( $t$-BHP) による強制酸化が， $F \mathrm{c} \gamma$ 受容体への結合及び $\mathrm{Fc} \gamma$ 受 容体活性化能に及ぼす影響について検討を行つた (Fig. 5)。SPR 法を用いた binding assayにより， EGFR, FcRn, Fc $\gamma$ RIIa, Fc $\gamma$ RIIIa のリコンビナント タンパク質に対する結合親和性を測定した結果，既 報の通り $t$-BHP を用いた酸化処理により FcRnに 対する結合解離定数 $\left(K_{\mathrm{D}}\right)$ が増大し結合親和性が 顕著に低下した一方で，抗原である EGFR 及び Fc $\gamma$ RIIa，Fc $\gamma$ RIIIa に対する結合に及ぼす影響は大 きくなかった，次に，これらの試料についてわれわ れの構築した Fc $\gamma$ 受容体発現レポーター細胞を用 いた cell-based assay により標的細胞存在下での $F c \gamma$ 受容体活性化能について検討を行つた結果, $t$ BHP による酸化処理は Fc $\gamma$ RIIIa 活性化能には影響 を及ぼさない一方で，Fc $\gamma$ RIIa 活性化能を顕著に低

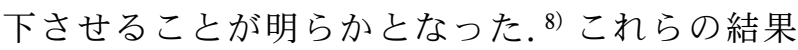
は，われわれの構築したアッセイ系を用いること で，リコンビナントタンパク質を用いた binding assay では検出困難な生物活性の低下を評価可能で あることを示すものであり，抗体医薬品の分子変化 体の特性解析における cell-based assay の重要性を 改めて認識させるものであると考える.

\section{6. おわりに}

本稿では抗体医薬品による免疫細胞活性化に係わ
る Fc $\gamma$ 受容体に着目し，われわれの樹立した Fc $\gamma$ 受容体発現レポーター細胞株を用いた Fc $\gamma$ 受容体 活性化能評価系について概説した。文頭で述べた通 り, $\mathrm{F} c \gamma$ 受容体の活性化は抗体医薬品の薬理作用の みならず，場合によっては意図せぬ免疫細胞の活性 化に伴う有害作用発現の発現とも密接に関与してお り，Fc $\gamma$ 受容体を介した ADCC 活性等を作用機序 とする抗体医薬品はもちろんのこと, Fc 領域を有 するすべての抗体医薬品について評価すべき特性の 1 つであると言える。われわれは今回紹介した 2 種 類の Fc $\gamma$ 受容体（Fc $\gamma$ RIIa，Fc $\gamma$ RIIIa）を発現する レポーター細胞株に加えて, 主要な遺伝子多型を含 むすべての Fc $\gamma$ 受容体の活性化を測定可能なレ ポーター細胞株を用いた評価系を構築中である。ま た，これらを活用して，抗体医薬品の品質評価のみ ならず，開発初期段階における抗体医薬品候補ク ローンの選別への応用や $\mathrm{F} c \gamma$ 受容体を介した抗体 医薬品の有害作用発現に係わるメカニズム解析等に も取り組んでおり，従来の天然型の IgG 骨格を有 する抗体医薬品はもとより，近年活発に開発がすす む改変型抗体医薬品等の実用化及び品質・安全性確 保に貢献したいと考えている。なお，われわれの樹 立した細胞株は，抗体医薬品開発や抗体に関連した 基礎研究に携わる多くの研究者に活用して頂けるよ う, 共同研究等の様々なかたちでの分与を行ってい る。御興味を持たれた方は筆者まで御連絡頂ければ 幸いである。

\section{謝辞本稿に関連した筆者らの研究の一部は,} 国立研究開発法人日本医療研究開発機構 (AMED) 医薬品等規制調和・評価研究事業，及び，医薬基盤 研究所・保健医療分野における基礎研究推進事業の 支援を受けてなされたものである.

利益相反＼cjkstart開示すべき利益相反はない.

\section{REFERENCES}

1) Gillis C., Gouel-Chéron A., Jönsson F., Bruhns P., Front. Immunol., 5, 254 (2014).

2) Nimmerjahn F., Ravetch J. V., Nat. Rev. Immunol., 8, 34-47 (2008).

3) Beck A., Reichert J. M., $m A b s, 4$, 419-425 (2012). 
4) Cameron F., McCormack P. L., Drugs, 74, 147-154 (2014).

5) Subramaniam J. M., Whiteside G., McKeage K., Croxtall J. C., Drugs, 72, 1293-1298 (2012).

6) Bournazos S., Ravetch J. V., Immunol. Rev., 268, 88-103 (2015).

7) DiLillo D. J., Ravetch J. V., Cell, 161, 10351045 (2015).

8) Tada M., Ishii-Watabe A., Suzuki T., Kawasaki N., PloS One, 9, e95787 (2014).

9) Schneider-Merck T., Lammerts van Bueren J. J., Berger S., Rossen K., van Berkel P. H.,
Derer S., Beyer T., Lohse S., Bleeker W. K., Peipp M., Parren P. W., van de Winkel J. G., Valerius T., Dechant M., J. Immunol., 184, 512-520 (2010).

10) Bertolotti-Ciarlet A., Wang W., Lownes R., Pristatsky P., Fang Y., McKelvey T., Li Y., Li Y., Drummond J., Prueksaritanont T., Vlasak J., Mol. Immunol., 46, 1878-1882 (2009) .

11) Wei Z., Feng J., Lin H. Y., Mullapudi S., Bishop E., Tous G. I., Casas-Finet J., Hakki F., Strouse R., Schenerman M. A., Anal. Chem., 79, 2797-2805 (2007). 